\title{
SCIENTISTS' PERCEPTIONS ON THE NATURE OF NANOSCIENCE AND ITS PUBLIC COMMUNICATION
}

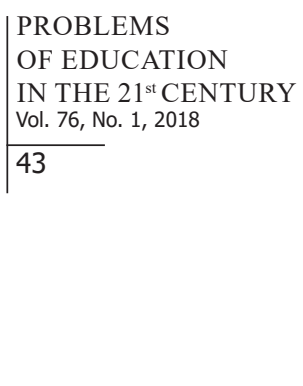

\author{
Antti Laherto \\ University of Helsinki, Finland \\ E-mail: antti.laherto@helsinki.fi \\ Frederike Tirre \\ University of Kiel, Germany \\ E-mail: ftirre@uv.uni-kiel.de
}

Ilka Parchmann, Lorenz Kampschulte

Leibniz Institute for Science and Mathematics Education (IPN), Germany

E-mail: parchmann@ipn.uni-kiel.de, kampschulte@ipn.uni-kiel.de

Stefan Schwarzer

Ludwig-Maximilian University of Munich, Germany

E-mail: stefan.schwarzer@cup.uni-muenchen.de

\begin{abstract}
Some level of understanding of and about nanoscience and nanotechnology (NST) has been suggested as being relevant in up-to-date scientific literacy for all. Research scientists working in these fields are central in current efforts to inform and engage the public in NST. Earlier research has shown that scientists can contribute to authentic science learning, but communication always entails roles that affect the choice of content. This study investigated NST researchers'views on the nature of their research and their preferences in NST communication. Eight experienced professors working in various fields of NST were interviewed. Semi-structured, in-depth interviews focused on the scientists' views on 1) the nature of their research, and 2) aspects of NST that should be communicated to the public. Qualitative content analysis of the interviews revealed that the themes the interviewees highlighted when describing their research (interdisciplinarity, size scale, methods, objects, nature of NST in general) were somewhat different from the ones they considered as important for communication to the public (applications and products, risks and benefits, visualizations). The results problematize the simplistic notion that exposure to real scientists would unquestionably enhance the authenticity of science learning. This study gives insight for research and development of science communication, especially scientists' role and training in it.
\end{abstract}

Keywords: authenticity, nanoscience, nature of science, science communication, scientist interviews.

\section{Introduction}

Nanoscience and nanotechnology ('NST' in the following) are an exemplar of a contemporary, rapidly developing field with several prospects of economically, societally and environmentally significant applications and implications. It seems likely that in the near future, citizens will have to make more and more decisions on NST-related issues - both at the personal level as consumers, and at the societal and global levels, regarding the future paths of NST (Baird, Nordmann, \& Schummer, 2004). Therefore, it has been argued that public understanding of these fields should be enhanced, so that people could better participate in the public debate 
Antti LAHERTO, Frederike TIRRE, Ilka PARCHMANN, Lorenz KAMPSCHULTE, Stefan SCHWARZER. Scientists' perceptions on the nature of nanoscience and its public communication

\section{PROBLEMS \\ OF EDUCATION \\ IN THE $21^{\text {st }}$ CENTURY Vol. 76, No. 1, 2018 \\ 44}

and make decisions on related issues (Castellini et al., 2007; Gilbert \& Lin, 2013; Healy, 2009).

Some level of understanding of these fields has been suggested as being relevant concerning up-to-date scientific literacy in modern societies (Gardner, Jones, Taylor, \& Forrester, 2010; Gilbert \& Lin, 2013; Laherto, 2010; Stevens, Sutherland, \& Krajcik, 2009). While these emerging fields have gained growing public interest and media attention, survey results have shown that people's awareness and knowledge of the fields have remained at a rather low level (Sahin \& Ekli, 2013; Waldron, Spencer, \& Batt, 2006). Furthermore, in addition to the public's awareness of the fields in question, public engagement in NST has been called for. In particular, the important ethical issues related to these fields have given rise to the need to engage the public in a deeper discourse on NST and its relations to society. (For further discussion, see Laherto, 2010). Such discourse requires an understanding not only of basic scientific concepts, but also of the processes underlying them, i.e. knowledge about the nature of science (Allchin, 2011; Erduran \& Dagher, 2014). During the past two decades, these demands have given rise to a large number of initiatives introducing NST to the general public.

Research scientists play the key role in all efforts of informal learning and public communication of contemporary research. Scientists communicate their research by giving popular lectures, writing popular articles and giving interviews in various media. Although large initiatives and activities are organized and managed by science communication professionals, the researchers of the field in question bring out the key content and represent science (Bauer \& Jensen, 2011). Public communication activities form a growing part of scientists' work (Horst, 2013). Concerning science education, scientists' direct impact on schools takes place not only through their visits to schools but more importantly through out-of-school settings such as visitor laboratories at universities (Glowinski, 2011), where researchers represent science both via personal contact and via materials developed by them.

Pertaining to the scientific content of such settings, the role of scientists has often been discussed using the multifaceted concept of authenticity (Buxton, 2006). A simplistic notion is that scientists represent 'real science' and thereby bring an authentic element to science communication. Similarly, authenticity of science education may be augmented if students meet real scientists, get a glimpse of their daily work, and access real research facilities (Glowinski, 2011) and work with original research data (Lee \& Butler, 2003). It is generally considered that such activities support situated learning and provide a fruitful way for making science education more authentic, valid and motivating (Adams, 2012; Braund \& Reiss, 2006). "Scientists in the classroom" interventions have changed students" views towards a more realistic image of scientists as persons and stronger engagement in scientific classroom activities (Laursen et al., 2006). Meeting scientists provides exposure (Elder, 1995) to scientific careers. Exposure is the notion that one's life course is heavily influenced by one's surroundings, and to be able to choose an alternative future, one has to be exposed to it.

However, authenticity of science communication and education entails much more than listening to scientists' perspectives (see e.g. Kapon, Laherto \& Levrini, 2016; Buxton, 2006; Rahm, Miller, Hartley, \& Moore, 2003), and as such, scientists' voice certainly does not guarantee an unquestionably authentic image of science. Some earlier research has shown that researchers may hold narrower views on the nature of science than expected (Peters-Burton \& Baynard, 2013). Furthermore, examining the scientists' input in science communication and education requires a closer look at modes of communication and researchers' perspectives and purposes in these activities. Studies on researchers' views on science communication have shown that the so-called deficit model is still a common, persistent view among scientists, but more modern models of dialogue and interactivity with the public are employed as well (Schibeci \& Williams, 2014). Several typologies of scientists' approaches in science communication have been suggested and used - for example, four types of knowledge exchange: professional science communication, deficit science communication, consultative science communication, and deliberative science communication (Schibeci \& Williams, 2014). On the basis of 20 scientists' views, Maja Horst (2013) identified three modes of representation of the perceived 
role of researchers: Expert (representing a field of expertise), Research Manager (representing an organization), and Guardian of Science (representing the institution of science). The role a scientist takes, i.e. her/his intention, deeply affects the nature and content of communication.

Due to the importance of authentic NST communication and scientists' key role in it, this research aims for an increased understanding of NST researchers' i) views on the nature of their research, and ii) aspects of their research they find important to communicate to the public. These views have been analysed and compared with each other and with the literature on science communication and the nature of NST. This analysis and comparison can bring out the potential challenges of NST communication and identify issues that should be considered when developing outreach initiatives and venues for NST.

The broader aim of this research is to analyse and deepen the authenticity of communication and informal learning of contemporary science. More specifically, the research reported here addressed the following research question: How do NST researchers characterize their research, and how is that in line with the aspects of NST they consider to be important to communicate to the public?

\section{Theoretical Background: the Nature of NST}

Nature of Science (NoS) is a central element in above-discussed authenticity, and one of the predominant concepts in research on science education as well as in reforms of science curricula. NoS education is uniformly advocated since understanding the scientific processes and the relationships between science and society is considered to be a crucially important element of scientific literacy for all (Allchin, 2011; Roberts, 2007; Wenning, 2006). However, both the content and the approaches of NoS teaching have remained under debate. The most influential attempt to consolidate the concept has been the 'consensus model' (Lederman, 2007) listing general characteristics of NoS such as tentativeness, non-linearity, theory-ladenness, distinction between theories and laws, the use of models, the role of creativity, and the social and cultural embeddedness (McComas \& Olson, 1998; Lederman, 2007). To articulate the latter of these better, the consensus view has recently been challenged by the Family Resemblance Approach (FRA) (Irzik \& Nola, 2011). The FRA aims to provide more elaborated, dynamic, holistic and systematic representation of science, not merely as epistemic inquiry but also as a social institution. The FRA considers science both as a cognitive-epistemic system and science as a social institution (Irzik \& Nola, 2011; Erduran \& Dagher, 2014).

Since the present research is contextualized within NST and the problems in public communication of that field, the theoretical background is here focused on NoS perspectives specific to NST. In order to be meaningful and useful, NoS views need to be scrutinized in a context (Rudolph, 2000; Tala \& Vesterinen, 2015). Despite the relative novelty of NST, during the past two decades, there has been a number of publications in the field of Science, Technology and Society (STS) studies employing philosophical, historical, analytical and ethical approaches to study the nature of these emerging fields (e.g. Baird, Nordmann \& Schummer, 2004; Brune et al., 2006; Cameron \& Mitchell, 2007; Hunt \& Mehta, 2006).

Despite the growing attention being paid to these fields, the concepts of nanoscience and nanotechnology have remained ambiguous and without a universally-accepted definition. The literature on the nature of NST (e.g. Baird, Nordmann, \& Schummer, 2004; Brune et al., 2006; Cameron \& Mitchell, 2007; Hunt \& Mehta, 2006), and textbooks and overviews on NST (e.g. Nalwa, 2004; Poole \& Owens, 2003) show that the field is a complex amalgam of various questions, methods, technologies and findings. Commonly, the nanometre scale of objects (together with the purposeful control of matter at that scale, and some aspect of novelty either in methods, findings or applications) serves as a justification for considering a field as nanoscience or nanotechnology. The scale is the main defining factor in the most influential definitions of NST, e.g. the relatively inclusive one presented by the European Union (for a collection and comparison of other definitions, see Palmberg, Dernis, \& Miguet, 2009):

PROBLEMS
OF EDUCATION
IN THE 21 $1^{\text {st }}$ CENTURY
Vol. 76, No. 1, 2018 
Antti LAHERTO, Frederike TIRRE, Ilka PARCHMANN, Lorenz KAMPSCHULTE, Stefan SCHWARZER. Scientists' perceptions on the nature of nanoscience and its public communication

\author{
PROBLEMS \\ OF EDUCATION \\ IN THE $21^{\text {st }}$ CENTURY \\ Vol. 76, No. 1,2018 \\ 46 \\ Nanosciences and nanotechnologies are new approaches to research and development that \\ concern the study of phenomena and manipulation of materials at atomic, molecular and macromolecular \\ scales, where properties differ significantly from those at a large scale.
}

(European Commission, 2005, p. 2)

The central scientific concepts of NST have been systematically assembled and analysed e.g. by Brune et al. (2006) and Stevens, Sutherland and Krajcik (2009), the latter from an educational viewpoint. Since the focus of the present research is not on scientific concepts but on the nature of the research on the nanoscale, we have reviewed that literature in the following. To begin with, the interdisciplinary nature of NST has raised epistemological interest. Many fields of NST clearly link two or more of the traditional disciplines or fields of research, mostly physics, chemistry, biology, material science, medicine and engineering. Many recent writings on modern scientific and technological literacy have emphasised such interdisciplinarity (see e.g. Kähkönen, Laherto, Lindell, \& Tala, 2016; Roberts, 2007). Interdisciplinary research in NST, comprising both cognitive-epistemic and socio-institutional dimensions (Kähkönen et al., 2016), is based on two ideas that provide common ground for researchers from different fields: the shared size scale of objects and shared technological visions (Schummer, 2004). Many expectations rest on this notion of interdisciplinarity, which has even been proposed as the deciding factor in the progress of NST (Brune et al., 2006). The idea that forthcoming scientific and technological breakthroughs will most likely occur at the intersections of traditional scientific disciplines is generally accepted, and synergetic effects are believed to give rise to innovative research. While reports concerning nanoscale research frequently highlight the necessity of interdisciplinarity, doubts also remain about the true state of interdisciplinarity in NST, rather describing it as a multidisciplinary field, criss-crossing but not dispelling the disciplinary barriers (Kähkönen et al., 2016; Schummer, 2004).

Philosophers have also pointed out the interesting relationship between nanoscience and nanotechnology. It has been suggested that the traditional, predominant way of thinking, which considers science and technology (or the natural and the engineering sciences) to be fundamentally different enterprises in the sense of purpose and function, fails in the context of NST (Brune et al., 2006). Besides nanoscience research focusing on the use of various instruments and equipment, the field also deals with artificially produced situations that depend on human actions and technical purposes. Here, observations and discoveries are made in relation to the states or properties of these artificial objects or events. Several scholars therefore argue that no clear distinction exists between understanding nature and modifying it (Schmidt, 2004). These categories, however, are not exclusive to nanoscience - rather, this merging of science and technology has always existed. This matter has been discussed using the concept of "technoscience" (Nordmann, 2004). This convergence of science and technology has been emphasised and accelerated in the case of NST (Kähkönen et al., 2016; Tala, 2009) and is, therefore, a noteworthy category of these fields.

Another epistemological category of NST also relevant for education is the central role of modelling and imaging. Brune et al. (2006, p. 53-57) argue that the discourse on NST is replete with an apparent confusion of models with descriptions of reality. Again, this problem is also well-known when learning more traditional science (Buckley \& Boulter, 2000), but it may be emphasised in the field of NST. Nanoscientists tend to use the models they have conceived in similar and straightforward ways as empirical descriptions are commonly used in everyday contexts, without emphasising that these conceptions are relevant only in the framework of certain theories, models, methodological decisions and purposes (Lenhard, 2004). Consequently, models are confused with what is being modelled. Such confusion is also of great concern in NST because of the extensive use of images in representing nanoscale objects and phenomena (Landau et al., 2009). The common conception of nanoscience "making atoms visible" is alleged to be problematic (Pitt, 2004), since the microscopy used in nanoscale research is epistemologically not an outright continuation of instruments such as the telescope or light microscope. 
Antti LAHERTO, Frederike TIRRE, Ilka PARCHMANN, Lorenz KAMPSCHULTE, Stefan SCHWARZER. Scientists' perceptions on the nature of nanoscience and its public communication

The results of the present research are discussed in the light of these issues pointed out in the literature on the nature of NST.

\section{Methodology of Research}

\section{General Approach}

The research question was addressed by an interview study with information-rich cases (Patton, 1990) that could provide in-depth knowledge about researchers' perspectives on the nature of NST and its communication. Semi-structured interviews with eight experienced NST researchers were carried out. This perspective from inside the research community was analysed and compared to the perspectives from the literature on the nature of NST explored above.

\section{Sample Selection}

The research employed purposeful sampling that is typical for qualitative inquiry with small samples (e.g. Miles \& Huberman, 1994; Patton, 1990). The eight interviewees were all full professors who had had several years of experience in research on NST. They had also been active in outreach measures: all of them had given many public lectures and interviews in the mass media, and given tours to visitor groups in their laboratories. Six of the professors were working in the Collaborative Research Center "Function by Switching" at the University of Kiel, Germany. Two additional interviewees had been chosen to avoid a too specific perspective; they were professors from the Department of Physics at the University of Helsinki, Finland. Although the purposeful sampling approach did not aim at a representative sample of NST researchers but rather on a profound investigation of information-rich cases (Patton, 1990), the professors in question were working on a wide variety of fundamental as well as applied NSTrelated research close to chemistry, physics, and materials science.

\section{Instrument and Procedures}

On the basis of the research question, the interviews carried out during this research included two topics that were discussed with the interviewees in two successive stages: 1) Characteristics of their NST research, and 2) Aspects of NST that should be communicated to the public.

Before the interview started, all professors were briefed in the same manner. The briefing guided the interviewees, in the first stage (topic 1), to describe their research in detail to the interviewers. The professors knew that the interviewers had a scientific background, although not specific to NST. The context of public communication was introduced only in the second stage of the interview, when discussing the aspects that should be communicated to the public (topic 2).

In the first stage, the professors were asked to describe their NST research in their own words and in their own context (topic 1). The semi-structured interview protocol included a number of open interview questions offering the interviewees the opportunity to shed light on their views of the nature of their research: What is "nano" in your research? Could you describe the process of one of your nano-related research projects? Is that typical for nanoscience research in general in your area? Do you think nanoscience research differs from other research in science?

In the second stage of the interview, the focus was shifted from professors' descriptions of their research to the issue of public communication (topic 2). This discussion was catalysed by questions: What aspects of your current NST-related research should be communicated to the public in order to give them an "authentic image"? Are these the aspects that are generally discussed when communicating NST research? If not, which aspects are? 
Antti LAHERTO, Frederike TIRRE, Ilka PARCHMANN, Lorenz KAMPSCHULTE, Stefan SCHWARZER. Scientists' perceptions on the nature of nanoscience and its public communication

OF EDUC

IN THE $21^{\text {st }}$ CENTURY Vol. 76, No. 1, 2018

48

All interviews were carried out in English. Although only one of the professors had it as native language, all of them were fluent in English. Each interview took 40-100 minutes, and all professors agreed to be audio-recorded and to the anonymous use of the collected data for research purposes.

\section{Data Analysis}

The audio recordings were first transcribed and then analysed through qualitative content analysis of the interviewee's responses in topics 1 and 2 separately. The content analysis was aimed at identifying and categorising emerging issues, similarities and analogies in interviewee's responses (cf. Patton, 1990), i.e. finding themes that characterise respondents' ideas concerning the research question.

The inductive method of qualitative analysis (Mayring, 2001) was employed to categorise the themes emerging from the interview data. Three of the authors carried out the analysis and categorization independently. The observed inter-rater reliability was already high during the first round of analysis and categorization. The disagreements were iteratively negotiated until consensus was found. The results presented in the next sections represent the consensus between the authors after three rounds of refinement.

\section{Results of Research}

\section{Topic 1: Characteristics of NST}

The themes that emerged from the analysis of the interviews on topic 1 (Characteristics of NST) are presented in Table 1. For each category, a short description has been provided. Under the description, we have chosen exemplary quotes from the interviewees. These quotes represent typical ideas categorised in this theme. The categories are listed in descending order, i.e. the themes in the first category were most frequently discussed by all interviewees, whereas the last category was discussed by only a few interviewees. The most important themes are discussed in the section following the table.

Table1. Interview topic 1 (characteristics of NST): the themes, their descriptions and exemplary quotes in descending order.

Topic 1: Characteristics of NST

\begin{tabular}{lll}
\hline Quotes (exemplary) & Description & Category \\
\hline $\begin{array}{l}\text { "interdisciplinarity is important due to varied instru- } \\
\text { ments needed"; "interdisciplinarity is what makes } \\
\text { nano research different from other science"; "in } \\
\begin{array}{l}\text { nano science it is natural to collaborate with other } \\
\text { fields, but it doesn't mean you see your colleagues } \\
\text { every day" }\end{array}\end{array} \begin{array}{l}\begin{array}{l}\text { Exchange of expertise/ } \\
\text { methods/results between } \\
\text { different research fields } \\
\text { (biology/chemistry/physics/ } \\
\text { material sciences/etc.) }\end{array} \\
\begin{array}{l}\text { "chemistry is always nano since molecules are on } \\
\text { that scale - but really, what makes nano science is } \\
\text { that you really look to nano scales [...]" }\end{array} \\
\begin{array}{l}\text { Description of size and } \\
\text { scale, nano as a scale to } \\
\text { operate on }\end{array}\end{array} \quad \rightarrow \quad$ Inter-disciplinarity \\
$\begin{array}{l}\text { "We must use microscopic methods, looking at } \\
\text { spectra etc. to make it visible"; "methodology is } \\
\text { very important"; "also laser experiments and AFM } \\
\text { [Atomic Force Microscope]" }\end{array} \quad \begin{array}{l}\text { Research methods used in } \\
\text { the field of nano research }\end{array}$
\end{tabular}$\quad \rightarrow \quad \begin{aligned} & \text { Methods \& instru- } \\
& \text { mentation }\end{aligned}$


Antti LAHERTO, Frederike TIRRE, Ilka PARCHMANN, Lorenz KAMPSCHULTE, Stefan SCHWARZER. Scientists' perceptions on the nature of nanoscience and its public communication

\begin{tabular}{|c|c|c|c|c|}
\hline $\begin{array}{l}\text { "metallic \& magnetic nanoparticles"; "carbon nano } \\
\text { tubes, graphene, nano clusters, nano wires and } \\
\text { thin films"; "So, we're interested in processes at } \\
\text { interfaces in condensed matter." }\end{array}$ & $\rightarrow$ & $\begin{array}{l}\text { Research objects and } \\
\text { structures on the nano } \\
\text { scale }\end{array}$ & $\rightarrow$ & $\begin{array}{l}\text { Objects \& struc- } \\
\text { tures }\end{array}$ \\
\hline $\begin{array}{l}\text { "everything starts with a good research question } \\
\text { that can be answered by the methods available"; } \\
\text { "systematically changing the system, explaining the } \\
\text { phenomena" }\end{array}$ & $\rightarrow$ & $\begin{array}{l}\text { Ideas, research questions, } \\
\text { hypotheses, methods, etc. }\end{array}$ & $\rightarrow$ & $\begin{array}{l}\text { Scientific process } \\
\text { (general) }\end{array}$ \\
\hline $\begin{array}{l}\text { "Utilizing properties in materials - make antibacte- } \\
\text { rial applications, magnetic window glass, electronic } \\
\text { applications, filters, plasmonics, church windows } \\
\text { (metallic nano particles). Create functional materi- } \\
\text { als." }\end{array}$ & $\rightarrow$ & $\begin{array}{l}\text { From research to products, } \\
\text { nano products on the } \\
\text { market }\end{array}$ & $\rightarrow$ & $\begin{array}{l}\text { Applications \& } \\
\text { products }\end{array}$ \\
\hline $\begin{array}{l}\text { "We take advantage of new physical properties of } \\
\text { materials, surface area vs. volume and quantum } \\
\text { effects (e.g. optical)"; "self-organization processes" }\end{array}$ & $\rightarrow$ & $\begin{array}{l}\text { Effects due to size of par- } \\
\text { ticles or structure, different } \\
\text { behaviour of material on } \\
\text { nano scale than on bigger } \\
\text { scales }\end{array}$ & $\rightarrow$ & $\begin{array}{l}\text { Quantum effects } \\
\text { \& size-dependent } \\
\text { properties }\end{array}$ \\
\hline $\begin{array}{l}\text { "[...] getting funding, hiring a postdoc or a PhD } \\
\text { student; additional proposals and adjusting the } \\
\text { direction of the research." }\end{array}$ & $\rightarrow$ & $\begin{array}{l}\text { Organizational aspects of } \\
\text { work, writing proposals, } \\
\text { teaching, etc. }\end{array}$ & $\rightarrow$ & $\begin{array}{l}\text { Organizational } \\
\text { process }\end{array}$ \\
\hline $\begin{array}{l}\text { "So, the nano is just one label you can put on your } \\
\text { research, if the subject you're dealing with has } \\
\text { something to do with nano sized objects, but I think } \\
\text { the scientific approaches are very, very similar." }\end{array}$ & $\rightarrow$ & $\begin{array}{l}\text { Differentiation and com- } \\
\text { parison between NST as a } \\
\text { combined field and single } \\
\text { fields of research (Chemis- } \\
\text { try, Physics, etc.) }\end{array}$ & $\rightarrow$ & $\begin{array}{l}\text { Differences (to } \\
\text { other sciences) }\end{array}$ \\
\hline
\end{tabular}

"Interdisciplinary research means we should build a new generation. [...] we try to understand the basics, so all of us we try to learn and to learn something like a baby [...] that we every day learn something new. And that is here important"

$\rightarrow \quad \begin{aligned} & \text { Societal implications }, \quad \rightarrow \quad \begin{array}{l}\text { Other goals of } \\ \text { research }\end{array} \\ & \text { learning }\end{aligned}$

"There has been a lot of the research, which is now branded as nanoscience research, was formally research in physics and chemistry, maybe today $\rightarrow$ Origin of field, novelty $\rightarrow$ History/novelty of people between physics and chemistry work more closely together than they used to do maybe 30 NST years ago."

The first theme (Table 1) that was discussed by all eight professors as a core characteristic of their NST research is its interdisciplinarity. The interviewees broadly discussed both the cognitive-epistemic and socio-institutional dimensions of interdisciplinarity, and considered such features as the essence of the field, and what makes it novel:"[NST] requires methods from physics, chemistry, engineering, sometimes medicine, biology"; "interdisciplinarity is what makes nano research different from other science."

However, the inherent interdisciplinarity of the field also presents challenges because the researchers are still trained in a disciplinary way: "Nano is an interdisciplinary story, and that means chemists can work with physicists and with biologists [...] That's not really working well, in my opinion. Because communication is very hard, background is totally different. We should have a researcher in the future, who does know what physics is, what chemistry is, what biology is, what engineering is ... a multi-educated researcher that would be interdisciplinary!" 
Antti LAHERTO, Frederike TIRRE, Ilka PARCHMANN, Lorenz KAMPSCHULTE, Stefan SCHWARZER. Scientists' perceptions on the nature of nanoscience and its public communication

\section{PROBLEMS \\ OF EDUCATION \\ IN THE $21^{\text {st }}$ CENTURY Vol. 76, No. 1, 2018}

According to the interviewees, the main common ground for interdisciplinary collaboration in NST is the shared dimension, the nanoscale (1-100 nm). Some of the professors mentioned the idea that NST is not actually a scientific field in itself, but a dimension in which they carry out research (in all fields of natural sciences). All interviewees emphasised the aspect that the systems to be examined cannot be seen by the bare eye nor a light microscope, and specific instruments are necessary to look into an invisible world. "Chemistry is always nano since, molecules are on that scale... but really, what makes nanoscience is that you really look to nanoscales"; "specific to nano research is that we cannot see the systems under research directly [...]." Nevertheless, the idea of the size scale as a deciding factor was problematic to some of the professors; they did not consider that their research and science in general is, or could be, defined by scale.

As a third major theme of what the scientists used in the characterizations of NST was methods and instrumentation. All the interviewees talked extensively about the instruments typically used in NST research that characterize their daily work. They included "spectroscopy", "laser experiments and AFM", "sputtering, thin film deposition, self-organized processes", "computer simulations and nano cluster deposition", and "scanning tunnelling microscopy". Many of the professors explained the central role of instruments in NST in terms of dimension, e.g. "we must use microscopic methods, looking at spectra etc. to make it visible". But also the applied nature of NST typically requires multiple techniques and methods: for example, a professor described his research on interfaces as requiring "scanning probe microscopic techniques, then also synchrotron based extra diffraction methods and other techniques like spectroscopic techniques, electrochemical techniques, which carry information about the interface".

Besides the methodology, the scientists' descriptions of their research were heavily focused on objects and structures that were not only studied but also created or developed in the process. Such objects and structures included "nano particles", "nanocomposite materials", "metallic \& magnetic nanoparticles"; "functional materials", "carbon nano tubes, graphene, nano clusters, nano wires and thin films".

When describing the nature of their NST research, the professors brought up several general features of the processes of science that are not specific to NST - for example, the need for good questions at the beginning and the ability to turn those questions into research. Few of the researchers mentioned the applications and products of NST as an element of their research and in the nature of NST.

\section{Topic 2: Aspects of NST important for communication to the public}

The main themes that emerged from the analysis of the interviews on topic 2 (aspects of NST that should be communicated to the public) are presented in Table 2. As in Table 1, the categories are illustrated by descriptions and exemplary quotes from the researchers and sorted in descending order, i.e. the themes in the first category were discussed the most by all interviewees, whereas the last category was discussed in some interviews only. The most important themes are then discussed in detail. 
Table2. Interview topic 2 (aspect of NST that the scientists consider important Vol. 76, No. 1, 2018 to communicate to the public): the themes, their descriptions and exemplary quotes in descending order.

Topic 2: Aspects of NST important for communication to the public

\begin{tabular}{llll}
\hline Quotes (exemplary) & Description & Category \\
\hline $\begin{array}{l}\text { "They'll [the public] probably be only interested in } \\
\text { nano-related applications and products in daily } \\
\text { life, because that's what they can relate to, that's } \\
\text { what they know." }\end{array}$ & $\rightarrow \begin{array}{l}\text { Nanotechnological prod- } \\
\text { ucts and applications }\end{array}$ & $\rightarrow \begin{array}{l}\text { Products \& applica- } \\
\text { tions }\end{array}$ \\
\hline $\begin{array}{l}\text { "the balance of taking advantage of the many new } \\
\text { opportunities and also taking care of the risks"; } \\
\text { "that risks can be controlled" "[...] you should also } \\
\text { identify the risk [in public communication]" }\end{array}$ & $\rightarrow \begin{array}{l}\text { Risks and benefits of NST } \\
\text { and nano products on the } \\
\text { market }\end{array}$ & $\rightarrow$ & Risks \& benefits \\
\hline $\begin{array}{l}\text { "[Pictures are] fascinating - a good way to promote } \\
\text { the ideas of nanoscience"; "beautiful images } \\
\text { of what nano objects look like"; "if I see, I can } \\
\text { imagine" }\end{array}$ & $\begin{array}{l}\text { Images (especially } \\
\text { produced by atomic force / } \\
\text { tunnelling microscopies) to } \\
\text { illustrate nanoscale objects }\end{array}$ & $\rightarrow$ & $\begin{array}{l}\text { Images \& visualisa- } \\
\text { tions }\end{array}$ \\
\hline
\end{tabular}

"[...] how the method works and what you can see with it; e.g. laser spectroscopy"; "showing the labs \& instruments; BUT you shouldn't go to $\quad \rightarrow \quad$ Methodology used in NST $\rightarrow \quad$ Scientific methods very specific processes since the public is not interested in it."

\begin{tabular}{|c|c|c|c|c|}
\hline $\begin{array}{l}\text { "If you succeed in that people see OK, nano is } \\
\text { something interesting and may potentially, you } \\
\text { know, make life better [...] that would be already } \\
\text { a lot." }\end{array}$ & $\rightarrow$ & $\begin{array}{l}\text { Actual and potential ben- } \\
\text { efits of nanotechnology }\end{array}$ & $\rightarrow$ & $\begin{array}{l}\text { Usefulness of } \\
\text { research }\end{array}$ \\
\hline $\begin{array}{l}\text { "[...] you can set a target and then work on that } \\
\text { target, work towards that target on a straight } \\
\text { route, but that's simply nonsense, that's not } \\
\text { how research works. [...] Science is not a linear } \\
\text { process. It's a highly non-linear process." }\end{array}$ & $\rightarrow$ & $\begin{array}{l}\text { Processes of NST, nature } \\
\text { of science }\end{array}$ & $\rightarrow$ & Scientific processes \\
\hline $\begin{array}{l}\text { "Convincing young people that nano science is an } \\
\text { attractive field and they should consider studying } \\
\text { science." }\end{array}$ & $\rightarrow$ & $\begin{array}{l}\text { Career options in the field } \\
\text { of NST }\end{array}$ & $\rightarrow$ & Career options \\
\hline $\begin{array}{l}\text { "not that important"; "quantum physics processes } \\
\text { etc. are so complicated that they are difficult to un- } \\
\text { derstand"; "I don't think the general public needs } \\
\text { to know very much about those technical details." }\end{array}$ & $\rightarrow$ & $\begin{array}{l}\text { Basic scientific concepts to } \\
\text { understand NST }\end{array}$ & $\rightarrow$ & $\begin{array}{l}\text { Scientific basis } \\
\text { (conceptual knowl- } \\
\text { edge) }\end{array}$ \\
\hline $\begin{array}{l}\text { "[...] things get smaller and smaller and smaller in } \\
\text { electronics etc. - we're now making whatever } 26 \\
\text { or } 28 \text { nanometre wires and circles" }\end{array}$ & $\rightarrow$ & Dimension of NST & $\rightarrow$ & Scale \\
\hline $\begin{array}{l}\text { "I like to emphasize always [...] that nano is some- } \\
\text { thing, which has always existed. So, there have } \\
\text { always been nanometre scale objects around us." }\end{array}$ & $\rightarrow$ & Origin of field, novelty & $\rightarrow$ & $\begin{array}{l}\text { History/novelty of } \\
\text { NST }\end{array}$ \\
\hline
\end{tabular}

While the researchers did not see products and applications as an important characteristic of their research (topic 1), they unanimously considered them to be the cornerstone of NST communication to the public: "You probably don't want to stress that [research] so much, but you want to talk more about the applications and products used in daily life." They saw this 
Antti LAHERTO, Frederike TIRRE, Ilka PARCHMANN, Lorenz KAMPSCHULTE, Stefan SCHWARZER. Scientists' perceptions on the nature of nanoscience and its public communication

\section{PROBLEMS \\ OF EDUCATION \\ IN THE $21^{\text {st }}$ CENTURY Vol. 76, No. 1, 2018 \\ 52}

as an important way to bring people into contact with NST because of the close connection to everyday life, and they think that focusing on applications raises interest in their work: "the applications make the nano science very concrete - people know what you are talking about when you talk about applications. I think every presentation, every public writing or presentation needs to have some part focusing on this." Especially the information and communication technology applications were seen as a good context for communication: "[For communication we need] something you can touch, something you can see... our results are usually in the computer." "[...] the electronics industry like chips, recording, everything related to information technology".

In connection to the NST applications, the interviewees emphasised that both risks and benefits of NST should be addressed in public communication. Communication measures should carefully bring forward "the balance of taking advantage of the many new opportunities and also taking care of the risks", and emphasise "that risks can be controlled." "We try first with something which is not in direct contact with people, because there are a lot of things that are still not clear. And that's also an important point, when you speak now about this story, then you should also identify the risk. I mean, if I make a product out of nano, then I should also identify how safe it is."

In addition, the scientists emphasised the importance of images and visualisations in public communication of NST. Illustrating nanoscale objects and phenomena by images generated with an atomic force microscope or scanning tunnelling microscope was seen as the main way to fascinate the public and also to make it concrete: "[the audience] would see what a molecule is - that they are real!"; "educational animations on the basis of computer simulations would be great". Interviewees acknowledged that not all nanoscience can be communicated by microscope images, but also in that case "we can make some nice graphics, colourful plots".

In accordance with the fundamental role of methods and instruments in their research, the interviewees also considered the scientific methods of NST as important for communicating to the public. Yet, many of the researchers were cautious about not going into too much in detail about their instruments: "showing the labs \& instruments; but you shouldn't go to very specific processes since the public is not interested in them."

\section{Discussion}

\section{Researchers' Views on the Nature of NST}

The themes the professors discussed when asked about the nature of their research culminated around the concept of interdisciplinarity. Both the cognitive-epistemic and socioinstitutional dimensions of interdisciplinarity (cf. Kähkönen et al., 2016) were used extensively in the researchers' descriptions. Closer analysis of the interviews revealed several factors that the professors saw underlying the interdisciplinary nature of their field. Interdisciplinarity seems to be based on the shared size scale of NST (cf. Schummer, 2004) - although the fundamental role of the dimension in research was questioned too. Also, the central role of methods and instruments, another frequent theme in scientists' descriptions of their research, was stated as a reason for interdisciplinary work: NST research typically requires a range of instruments and that is why collaboration with other fields and their laboratories is needed. The instrumentation available is crucial in all steps of the process, including setting research questions. The interviewees' descriptions of the technological nature and the fundamental role of artificial objects and structures in NST research seem to be in line with the notions of the techno-scientific nature of the field (Nordmann, 2004; Tala, 2009) as discussed in the philosophical literature (see theoretical background).

Despite the emphasis on interdisciplinary features, the interviewees did not seem to uphold a reductionist view of NST unifying the traditional disciplines (cf. Brune et al., 2006; Schmidt, 2004). Rather, they saw the interdisciplinary collaboration as being strictly structured - and 
also limited - by the disciplinary borders. Many researchers hoped and anticipated the deeper interdisciplinarity that would come from the next generation of researchers with thoroughly interdisciplinary training. Until that, the interviewees consider NST to be a multidisciplinary rather than a truly interdisciplinary field (cf. Schummer, 2004).

\section{Researchers' Views on NST Communication}

Interestingly, the themes the interviewees highlighted when describing their research were somewhat different from the ones they considered as important for communicating to the public. The latter were applications and products (due to their close connection to everyday life), risks and opportunities (due to the strong interests and negative attitudes the public is perceived to have), and visualizations (due to their fascination). They did not see the conceptual knowledge, methodology or most features of the nature of NST as interesting or accessible to the public. This is at least partly connected to the interviewees' very low estimation of public's understanding of NST.

It is noteworthy that the researchers interviewed did not see the value of communicating the scientific process or phenomena, but that communication should go directly to applications and their implications. The scientific conceptual understanding was seen as being completely out of reach to the public because of its complexity. They did not express interest in communicating the scientific basics of nanoscale phenomena and properties, nor even the size-dependent properties that are not based on quantum mechanics but more simply on the surface-volume ratio ('scaling effects').

Among the characteristics of their NST research, the scientists thought that only the instrumentation was important for communicating to the public. They clearly did not consider the interdisciplinary processes or other epistemological elements as interesting or relevant for the broader audience. While their descriptions of their research were replete with references to the dimension, they did not see the size scale as a key issue of to communicate. Yet, some of the scientists recognised that the 'smallness' of the nanoscale is a fascinating thing to understand for the lay people.

The professors' emphasis on applications, products, benefits and risks of NST in their public communication seems to be motivated by their understanding of the public's interests and needs. Indeed, according to surveys and polls, the public is only interested in these aspects of NST (e.g. Waldron, Spencer \& Batt, 2006; Sahin \& Ekli, 2013). Also, science teachers have considered applications and risks as the most educationally significant aspects of NST (Laherto, 2011).

The researchers interviewed for this research were aware of the power of illustrations in NST communication, and wanted to use them extensively to raise fascination and interest. They did not discuss the need to problematize model-based interpretations, or express concerns about the risks of epistemological misunderstandings (cf. Landau et al., 2009; Pitt, 2004; Laherto, 2013).

\section{Implications}

The results of this research problematize the emergence of authenticity in science learning and communication. Scientists 'automatically' bring a touch of authenticity into science communication (Braund \& Reiss, 2006). However, as discussed in the introduction, improving the authenticity of science learning and communication certainly requires more than "listening to researchers" (cf. Kapon, Laherto \& Levrini, 2016; Buxton, 2006; Rahm et al., 2003). Scientists may adopt various roles when communicating to the public. According to the results from the present research, it seems that NST researchers may tend to take the role of a Guardian of Science in public communication (Horst, 2013). The professors interviewed are inclined to tell the public about general applications and societal issues, rather than communicate 
Antti LAHERTO, Frederike TIRRE, Ilka PARCHMANN, Lorenz KAMPSCHULTE, Stefan SCHWARZER. Scientists' perceptions on the nature of nanoscience and its public communication

\section{PROBLEMS \\ OF EDUCATION \\ IN THE $21^{\text {st }}$ CENTURY Vol. 76, No. 1, 2018 \\ 54}

the processes of science as they would probably do if they took the role of an Expert in Horst's (2013) model.

Another interesting finding is that while the risks of NST are not a central topic in the daily work of the researchers, they still are inclined to address risks in public communication because of the perceived importance of risks. Generally, researchers are untrained or uncertain in risk communication (Gardner et al., 2017), but in the present research, the researchers were at least very keen on communicating risks associated with NST. The results call for added emphasis on risk communication in researcher training.

The scientists' views gained from the interviews were helpful in the development of research-based learning stations for school students in the student lab of the Collaborative Research Center "Function by Switching" at the University of Kiel, on the topics of nanotechnology and atomic force microscopy (Schwarzer et al., 2015).

\section{Limitations}

All conclusions from these results must acknowledge the small sample (eight interviewees) and lack of representativeness. But the present research does not culminate in generalisations to larger group of researchers. The choice of qualitative approach and purposeful sampling (Patton, 1990) was driven by conceptual questions, not by concerns for representativeness (cf. Miles \& Huberman, 1994). The aim was to get an in-depth understanding of the potential conflicts between how scientists see their research and how they want to communicate it to the public. The researchers were very experienced in both research and in public communication and therefore able to provide in-depth information on the issues in question.

The main challenge to validity of this research seems to arise from the research design. It must be acknowledged that the interviewees also had a communicational "role" (cf. Horst, 2013) when describing the nature of their research in the first part of the interview. We tried to reduce the blurring of the research questions by making a clear distinction between the two parts and objectives of the interviews. The context of public communication was mentioned only when entering the second stage (topic 2) of the interview. Yet, in future research the reliability could be enhanced by employing multiple methods: for instance, by responding to the first part of the research question with an interview with implicit questions, and then by analysing scientists' actual outreach measures (public talks etc.) to respond to the latter part of the research question.

\section{Conclusions}

To sum up, the interviewees argued that nanoscience can be taught and communicated in an authentic way without focusing on the scientific conceptual knowledge or the main features in the nature of the field. According to the professors interviewed, outreach measures should try to deliver an overview of the whole field and useful applications rather than knowledge of a specific research topic or the scientific basis of the field (e.g. quantum mechanics). While the NST professors describe their research in terms of interdisciplinary processes and the size scale, they do not consider such features that relevant or interesting to the broader audience.

Given the increasingly important role of researchers in the public communication of NST and other contemporary science, the results may be generally useful in research and development of science communication. The results of this research are critical of the simplistic notion, common in science education literature, that exposure to real scientists would automatically enhance the authenticity of science learning. If an understanding of the nature of science is considered to be an element in such authenticity, more elaboration and viewpoints are needed in public communication.

This research brought out researchers' views of both cognitive-epistemic and socioinstitutional elements of the nature of contemporary science. It gives insight for research on science communication, and development of outreach initiatives and informal learning settings 
Antti LAHERTO, Frederike TIRRE, Ilka PARCHMANN, Lorenz KAMPSCHULTE, Stefan SCHWARZER. Scientists' perceptions on the nature of nanoscience and its public communication

on NST. It also highlighted the need for researcher training in public communication and, for Vol. 76, No. 1, 2018 example, in dealing with the public's perception of risk.

\section{Acknowledgement}

The authors would like to thank the six professors from the Collaborative Research Center 677 "Function by Switching" at the Christian-Albrechts-University in Kiel, Germany, and the two professors from the Department of Physics at the University of Helsinki, Finland, for their time and good-will to participate in this research. Furthermore, the authors are grateful for the financial support by the German Research Association (DFG) and the expertise of colleagues in the field.

\section{References}

Adams, J. (2012). Schools and informal science settings: Collaborate, co-exist, or assimilate? Cultural Studies of Science Education, 7 (2), 409-416.

Allchin, D. (2011). Evaluating knowledge of the nature of (whole) science. Science Education, 95 (3), 518-542.

Baird, D., Nordmann, A., \& Schummer, J. (Eds.). (2004). Discovering the nanoscale. Amsterdam: IOS Press.

Bauer, M. W., \& Jensen, P. (2011). The mobilization of scientists for public engagement. Public Understanding of Science, 20, 3-11.

Braund, M., \& Reiss, M. (2006). Towards a more authentic science curriculum: The contribution of outof-school learning. International Journal of Science Education, 28 (12), 1373-1388.

Brune, H., Ernst, H., Grunwald, A., Grünwald, W., Hofmann, H., Krug, H., Janich, P., Mayor, M., Rathgeber, W., Schmid, G., Simon, U., Vogel, V., \& Wyrwa, D. (2006). Nanotechnology: Assessment and perspectives. Berlin Heidelberg: Springer.

Buckley, B., \& Boulter, C. (2000). Investigating the role of representations and expressed models in building mental models In J. Gilbert \& B. Carolyn (Eds.), Developing models in science education (pp. 119-136). Dordrecht: Kluwer Academic Publishers.

Buxton, C. A. (2006). Creating contextually authentic science in a "low-performing" urban elementary school. Journal of Research in Science Teaching, 43 (7), 695-721.

Cameron, N., \& Mitchell, M. (2007). Nanoscale: Issues and perspectives for the nano century. Hoboken, NJ: John Wiley \& Sons.

Castellini, O., Welejko, G., Holladay, C., Theim, T., Zenner, G., \& Crone, W. (2007). Nanotechnology and the public: Effectively communicating nanoscale science and engineering concepts. Journal of Nanoparticle Research, 9 (2), 183-189.

Elder, G. H. (1995). The life course paradigm: Social change and individual development. In P. Moen, G. H. Elder, \& K. Luscher (Eds.), Examining lives in context: Perspectives on the ecology of human development (pp. 101-139). Washington, DC: American Psychological Association.

Erduran, S., \& Dagher, Z. (2014). Reconceptualizing the nature of science for science education: Scientific knowledge, practices and other family categories. Dordrecht: Springer.

European Commission (2005). Nanosciences and nanotechnologies: An action plan for Europe 20052009. Belgium: European Communities.

Gardner, G., Jones, G., Taylor, A., \& Forrester, J. (2010). Students' risk perceptions of nanotechnology applications: Implications for science education. International Journal of Science Education, 32 (14), 1951-1969.

Gardner, G., Jones, G., Albe, V., Blonder, R., Laherto, A., Macher, D., \& Paechter, M. (2017). Factors influencing postsecondary STEM students' views of the public communication of an emergent technology: A cross-national study from five universities. Research in Science Education, 47 (5), 1011-1029.

Gilbert, J., \& Lin, H. (2013). How might adults learn about new science and technology? The case of nanoscience and nanotechnology. International Journal of Science Education, Part B. Communication and Public Engagement, 3 (3), 267-292. 
Antti LAHERTO, Frederike TIRRE, Ilka PARCHMANN, Lorenz KAMPSCHULTE, Stefan SCHWARZER. Scientists' perceptions on the nature of nanoscience and its public communication

\section{PROBLEMS \\ OF EDUCATION \\ IN THE $21^{\text {st }}$ CENTURY Vol. 76, No. 1, 2018 \\ 56}

Glowinski, I. (2011). Student labs on a university campus as a type of out-of-school learning environment: Assessing the potential to promote students' interest in science. International Journal of Environmental and Science Education, 6 (4), 371-392.

Healy, N. (2009). Why nano education? Journal of Nano Education, 1 (1), 6-7.

Horst, M. (2013). A field of expertise, the organization, or science itself? scientists' perception of representing research in public communication. Science Communication, 35 (6), 758-779.

Hunt, G., \& Mehta, M. (Eds.) (2006). Nanotechnology: Risk, ethics and law. London: Earthscan.

Irzik, G., \& Nola, R. (2011). A family resemblance approach to the nature of science for science education. Science \& Education, 20, 591-607.

Kapon, S., Laherto, A., \& Levrini, O. (2016). Conceptualizing authenticity and relevance of science education in interactional terms. In Looi, C. K., Polman, J. L., Cress, U., \& Reimann, P. (Eds.), Transforming learning, empowering learners: The international conference of the learning sciences (ICLS) 2016, Volume 2 (pp. 843-846). Singapore: International Society of the Learning Sciences.

Kähkönen, A., Laherto, A., Lindell, A., \& Tala, S. (2016). Interdisciplinary nature of nanoscience: Implications for education. In K. Winkelman, \& B. Bhutan (Eds.), Global perspectives of nanoscience and engineering education (pp. 35-81). Science Policy Reports. Switzerland: Springer.

Laherto, A. (2010). An analysis of the educational significance of nanoscience and nanotechnology in scientific and technological literacy. Science Education International, 21 (3), 160-175.

Laherto, A. (2011). Incorporating nanoscale science and technology into secondary school curriculum: Views of nano-trained science teachers. Nordic Studies in Science Education, 7 (2), 126-139.

Laherto, A. (2013). Informing the development of science exhibitions through educational research. International Journal of Science Education, Part B: Communication and Public Engagement, 3 (2), 121-143.

Landau, J., Groscurth, C., Wright, L., \& Condit, C. (2009). Visualizing nanotechnology: The impact of visual images on lay American audience associations with nanotechnology. Public Understanding of Science, 18 (3), 325-337.

Laursen, S., Liston, C., Thiry, H., \& Graf, J. (2006). What good is a scientist in the classroom? Participant outcomes and program design features for a short-duration science outreach intervention in K-12 classrooms. Life Sciences Education, 6 (1), 49-64.

Lee, H., \& Butler, N. (2003). Making authentic science accessible to students. International Journal of Science Education, 25 (8), 923-948.

Lederman, N. G. (2007). Nature of science: Past, present, and future. In Abell, S. K. \& Lederman, N. G. (Eds.), Handbook of research on science education. Mahwah, NJ: Erlbaum, 831-879.

Lenhard, J. (2004). Nanoscience and the janus-faced character of simulations. In D. Baird, A. Nordmann \& J. Schummer (Eds.), Discovering the nanoscale (pp. 93-100). Amsterdam: IOS Press.

Mayring, P. (2001). Combination and integration of qualitative and quantitative analysis. Forum: Qualitative Social Research, 2 (1), Art. 6.

McComas, W., \& Olson, J. (1998). The nature of science in science education. Science and Education, 7 (6), 511-523.

Miles, M., \& Huberman, A. (1994). Qualitative data analysis (2nd Ed.). Thousand Oaks, CA: SAGE.

Nalwa, H. S. (Ed.). (2004). Encyclopedia of nanoscience and nanotechnology. Stevenson Ranch, CA: American Scientific Publishers.

Nordmann, A. (2004). Molecular disjunctions: Staking claims at the nanoscale. In D. Baird, A. Nordmann \& J. Schummer (Eds.), Discovering the nanoscale (pp. 51-62). Amsterdam: IOS Press.

Palmberg, C., Dernis, H., \& Miguet, C. (2009). Nanotechnology: An overview based on indicators and statistics. STI Working Paper 2009/7. Organisation for Economic Co-operation and Development (OECD).

Patton, M. (1990). Qualitative evaluation and research methods. Newbury Park, CA: Sage Publications.

Peters-Burton, E., \& Baynard, L. R. (2013). Network analysis of beliefs about the scientific enterprise: A comparison of scientists, middle school science teachers and eighth-grade science students. International Journal of Science Education, 35 (16), 2801-2837.

Pitt, J. (2004). The epistemology of the very small. In D. Baird, A. Nordmann \& J. Schummer (Eds.), Discovering the nanoscale (157-164). Amsterdam: IOS Press.

Poole, C. P., \& Owens, F. J. (2003). Introduction to nanotechnology. Hoboken, NJ: John Wiley \& Sons. 
Antti LAHERTO, Frederike TIRRE, Ilka PARCHMANN, Lorenz KAMPSCHULTE, Stefan SCHWARZER. Scientists' perceptions on the nature of nanoscience and its public communication

Rahm, J., Miller, H. C., Hartley, L., \& Moore, J. C. (2003). The value of an emergent notion of authenticity: Examples from two student/teacher-scientist partnership programs. Journal of Research in Science Teaching, 40 (8), 737-756.

Roberts, D. A. (2007). Scientific literacy/Science literacy. In S. K. Abell, \& N. G. Lederman (Eds.), Handbook of research on science education (pp. 729-780). Mahwah, NJ: Lawrence Erlbaum Associates.

Rudolph, J. L. (2000). Reconsidering the 'Nature of Science' as a curriculum component. Journal of Curriculum Studies, 32 (3), 403-419.

Sahin, N., \& Ekli, E. (2013). Nanotechnology awareness, opinions and risk perceptions among middle school students. International Journal of Technology and Design Education, 23 (4), 867-881.

Schibeci, R. A., \& Williams, A. J. (2014). Science communication and desalination research: Water experts' views. International Journal of Science Education Part B, 4 (1), 92-106.

Schmidt, J. (2004). Unbounded technologies: Working through the technological reductionism of nanotechnology. In D. Baird, A. Nordmann \& J. Schummer (Eds.), Discovering the nanoscale (pp. 35-50). Amsterdam: IOS Press.

Schummer, J. (2004). Interdisciplinary issues in nanoscale research. In D. Baird, A. Nordmann \& J. Schummer (Eds.), Discovering the nanoscale (pp. 9-20). Amsterdam: IOS Press.

Schwarzer, S., Akaygun S., Sagun-Gokoz, B., Anderson, S. \& Blonder, R. (2015). Using atomic force microscopy in out-of-school settings -two case studies investigating the knowledge and understanding of high school students. Journal of Nano Education, 7 (1), 10-27.

Stevens, S., Sutherland, L., \& Krajcik, J. (2009). The big ideas of nanoscale science and engineering. Arlington, VA: NSTA Press.

Tala, S. (2009). Unified view of science and technology for education: Technoscience and technoscience education. Science \& Education, 18, 275-298.

Tala, S., \& Vesterinen, V.-M. (2015). Nature of science contextualized: Studying nature of science with scientists. Science and Education, 24 (4), 435-457.

Waldron, A., Spencer, D., \& Batt, C. (2006). The current state of public understanding of nanotechnology. Journal of Nanoparticle Research, 8(5), 569-575.

Wenning, C. (2006). Assessing nature-of-science literacy as one component of scientific literacy. Journal of Physics Teacher Education Online, 3 (4), 3-14.

Received: December 23, 2017

Accepted: February 21, 2018

\begin{tabular}{|c|c|}
\hline Antti Laherto & $\begin{array}{l}\text { PhD, Lecturer, University of Helsinki, Faculty of Educational Sciences, Department } \\
\text { of Education, P.O. Box } 9 \text { (Siltavuorenpenger 5A), Fl-00014 Helsinki, Finland. } \\
\text { E-mail: antti.laherto@helsinki.fi }\end{array}$ \\
\hline Frederike Tirre & $\begin{array}{l}\text { PhD, Researcher, University of Kiel, Cluster of Excellence "The Future Ocean", } \\
\text { Germany. } \\
\text { E-mail: ftirre@uv.uni-kiel.de }\end{array}$ \\
\hline Ilka Parchmann & $\begin{array}{l}\text { PhD, Professor, Leibniz Institute for Science and Mathematics Education (IPN), } \\
\text { Olshausenstraße 62, D-24118 Kiel, Germany. } \\
\text { E-mail: parchmann@@ipn.uni-kiel.de } \\
\text { Website: https://www.ipn.uni-kiel.de/en/the-ipn/departments/chemistry-education/ } \\
\text { staff/parchmann-ilka?set_language=en }\end{array}$ \\
\hline Lorenz Kampschulte & $\begin{array}{l}\text { PhD, Researcher, Leibniz Institute for Science and Mathematics Education (IPN), } \\
\text { Olshausenstraße 62, D-24118 Kiel, Germany. } \\
\text { E-mail: kampschulte@ipn.uni-kiel.de } \\
\text { Website: https://www.ipn.uni-kiel.de/en/the-ipn/departments/chemistry-education/ } \\
\text { staff/kampschulte-lorenz?set_language=en }\end{array}$ \\
\hline Stefan Schwarzer & $\begin{array}{l}\text { PhD, Professor, Ludwig-Maximilian University of Munich, Butenandtstr. 5-13, } \\
81377 \text { Munich, Germany. } \\
\text { E-mail: stefan.schwarzer@cup.uni-muenchen.de }\end{array}$ \\
\hline
\end{tabular}

